\title{
Analyses of severe acute maternal morbidity in Slovakia during years 2012-2016
}

\author{
Kristufkova A, Borovsky M, Danis J, Dugatova M, Levayova B, Korbel M \\ 1st Department of Gynaecology and Obstetrics, Faculty of Medicine, Comenius University, \\ Bratislava, Slovakia. a.kristufkova@gmail.com
}

\begin{abstract}
AIM: Severe acute maternal morbidity (SAMM) is a state of the woman, when she nearly died, but survived. The aim of study was to find out the exact incidence of SAMM in Slovakia, establishment of functional surveillance system and improve quality of health care.

MATERIALS AND METHODS: The regular annual analyses of SAMM cases in Slovakia from January $1^{\text {st }}$ 2012 to December $31^{\text {st }}$ 2016. Observed SAMM included: peripartum haemorrhage, peripartum hysterectomy, uterine rupture, abnormally invasive placenta, HELLP syndrome, eclampsia, sepsis, transport to intensive care unit or anaesthesiology and non-fatal amniotic fluid embolism.

RESULTS: The response rate of questionnaires was $84.8 \%$. The overall confirmed incidence of SAMM was $6.35 / 1,000$ births $(95 \% \mathrm{Cl} 6.03-6.67)$. The most often causes of SAMM were: peripartum haemorrhage (2.1/1,000 births), transport to intensive care unit or anaesthesiology (1.46/1,000 births), peripartum hysterectomy $(0.84 / 1,000$ births $)$ and HELLP syndrome $(0.63 / 1,000$ births). The average age of women with SAMM was 30.3 years (14-46) and average parity was 1.16 (0-15).

CONCLUSION: The incidence of SAMM and especially incidence of peripartum haemorrhage and peripartum hysterectomy in Slovakia is one of the highest in Europe. To decrease incidence and improve management and outcome of patients, regular audit of SAMM is needed (Tab. 3, Fig. 2, Ref. 30). Text in PDF www.elis.sk. KEY WORDS: severe acute maternal morbidity, surveillance system, severe postpartum haemorrhage, peripartum hysterectomy, eclampsia, HELLP syndrome, abnormally invasive placenta, uterine rupture, sepsis, amniotic fluid embolism, transport to intensive care unit or anaesthesiology.
\end{abstract}

\section{Introduction}

Severe acute maternal morbidity (SAMM) is a state of the woman, when she nearly died, but survived. This emergency situation occurred during the pregnancy, labour or within 42 days after the end of pregnancy (1). According to used criteria worldwide incidence of SAMM is differ (2).

In 2010 The International Network of Obstetric Survey Systems (INOSS) was created. INOSS is a multi-country collaboration formed to facilitate studies of uncommon and severe complications of pregnancy and childbirth e.g. SAMM. For very rare conditions such collaborations may provide the only route to achieve high quality evidence to guide practice and improve the health care $(3,4)$.

The Slovak Obstetric Survey System (SOSS) is the system established for better surveillance of SAMM in Slovakia and to improve the outcome of mothers. SOSS was established in year 2012, after the close cooperation with the United Kingdom Obstetric Surveillance System (UKOSS - history started in 2005 year) due to "epidemy" of fatal amniotic fluid embolism in the years 2009 and 2010 in Slovakia. This first collaboration raised into a comparison

1st Department of Gynaecology and Obstetrics, Faculty of Medicine, Comenius University, Bratislava, Slovakia

Address for correspondence: A. Kristufkova, MD, PhD, 1st Department of Gynaecology and Obstetrics, Faculty of Medicine, Comenius University, Antolska 11, SK-851 07 Bratislava, Slovakia. of amniotic fluid embolism cases and to comparison of perinatal outcomes between Slovakia and UK $(5,6)$. Since 2012 SOSS work on active surveillance of SAMM in Slovakia and as a member of INOSS too $(1,7-11)$.

\section{Materials and methods}

Primary outcome of this study was to find out the exact incidence of SAMM in Slovakia during years 2012-2016 and to performed expert analysis of all these cases. The secondary outcome was the establishment of functional surveillance system of obstetric complication those are responsible for SAMM in Slovakia.

The work is a population based prospectively annually collected data about the incidence of SAMM cases in Slovakia since January 1 st 2012 to December 31st 2016. The numbers of causes of severe acute maternal morbidities: peripartum haemorrhage, peripartum hysterectomy, uterine rupture, abnormally invasive placenta, HELLP syndrome, eclampsia, sepsis, transport to intensive care unit or anaesthesiology and non-fatal amniotic fluid embolism (definitions in Table 1) were annually announced to the section of perinatal medicine of Slovak Society of Obstetrics \& Gynaecology. Thereafter all Slovak obstetric hospital received the questionnaires to report each maternal morbidity. Detailed analysis all cases of maternal morbidity and confirmed/disconfirmed the maternal morbidity according to the definition (Tab. 1) was done by 
Tab. 1. Definition of severe acute maternal morbidities observed by Slovak Obstetric Survey System (source: SOSS).

\begin{tabular}{|c|c|}
\hline Maternal morbidity & Definition \\
\hline Severe peripartum haemorrhage & 4 and more transfusion units of red blood cells or whole blood \\
\hline Peripartum hysterectomy & Hysterectomy done during the labour or within 48 hours postpartum \\
\hline Abnormally invasive placenta & $\begin{array}{l}\text { Placenta accreta, increta, percreta } \\
\text { - Histologically confirmed } \\
\circ \text { after the hysterectomy or } \\
\circ \text { after the curettage with proof of chorionic villi in myometrium } \\
\text { - Antenatally proved by ultrasound or magnetic resonance in case of leaving placenta in situ }\end{array}$ \\
\hline Uterine rupture & $\begin{array}{l}\text { Uterine rupture in pregnancy or during labour (also in the scar) with need of: } \\
\text { - laparotomy } \\
\text { - suture or } \\
\text { - hysterectomy }\end{array}$ \\
\hline Eclampsia & Present of eclamptic seizure \\
\hline HELLP syndrome & 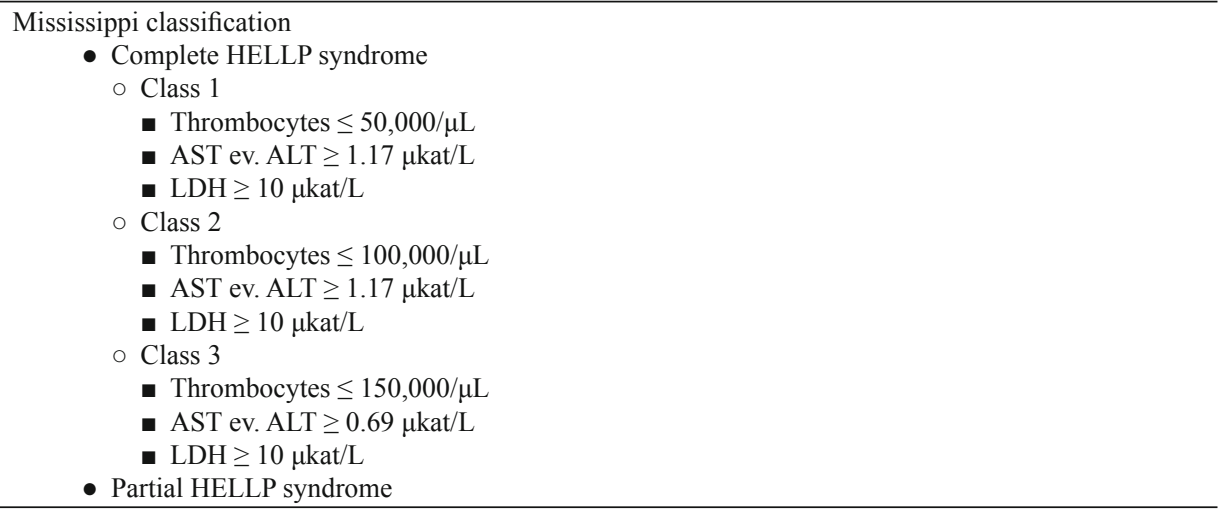 \\
\hline Sepsis & $\begin{array}{l}\text { Pregnant or women within } 6 \text { weeks postpartum with diagnosis of severe sepsis (without regard on focus of } \\
\text { infection) } \\
\text { - Clinical diagnosis of sepsis: } \\
\text { - Body temperature }<36^{\circ} \mathrm{C} \text { or }>38^{\circ} \mathrm{C} \text { minimum } 2 \text { measurements after } 4 \text { hours } \\
\text { - Pulls }>100 / \text { min., minimum } 2 \text { measurements after } 4 \text { hours } \\
\text { - Tachypnoea }>20 / \text { min., minimum } 2 \text { measurements after } 4 \text { hours } \\
\text { - Leucocytes }>17 \times 10^{9} \text { or }<4 \times 10^{9} \text { or }>10 \% \text { immature forms of leucocytes by } 2 \text { measurements } \\
\end{array}$ \\
\hline Non-fatal amniotic fluid embolism & $\begin{array}{l}\text { Diagnosis per exclusionem } \\
\text { - Acute hypotension, tachycardia } \\
\text { - Or cardiac arrest } \\
\text { - acute hypoxia } \\
\text { - coagulopathy } \\
\text { - dyspnoea } \\
\text { - sudden unconsciousness or seizures of unknown origin }\end{array}$ \\
\hline $\begin{array}{l}\text { Transport to intensive care unit } \\
\text { or anaesthesiology }\end{array}$ & $\begin{array}{l}\text { The state of pregnant women or women during or after the labour that has needed the transport to intensive } \\
\text { care unit or anaesthesiology department }\end{array}$ \\
\hline
\end{tabular}

expert committee of SOSS. The whole process of confirmation is done on the Figure 1. The analyse was finalised in April 30th 2019.

The statistical systems Software STATA 12.SE was used for analyses. The incidence of the severe acute maternal morbidity was count per 1,000 births with $95 \%$ confidence interval (CI). To compare the data the $\chi^{2}$-test or Fisher's exact test were used. The comparison was presented as relative risk (RR) with $95 \%$ CI. p $<0.05$ was considered as statistically significant.

\section{Results}

During years 2012-2016 the response rate was nearly $85 \%$ $(84.8 \%)$. The lowest response rate was in the year $2015(71.5 \%)$, the highest in the year 2013 (95\%).
The confirmed incidence of SAMM during years 2012-2016 was $6.35 / 1,000$ births ( $95 \%$ CI 6.03-6.67). The confirmed incidence was significantly lower than the firstly announced incidence RR 0.67 (95\% CI 0.62-0.71; $<<0.001)$. The same was observed after the expert analyses and confirmation from the responding departments with documented SAMM - RR 0.70 (95\% CI 0.65 - 0.75; $\mathrm{p}<0.001)$. The exact incidence in separate years and overall incidence is in the Figure 2.

The incidence of all observed SAMM in Slovakia during years 2012-2016 is in the Table 2. The most often cause of SAMM was the peripartum haemorrhage and the transport of women to the intensive care unit or anaesthesiology.

The average age of women with SAMM was 30.3 years (14-46). The avarage parity of women was 1.16 births $(0-15)$. 


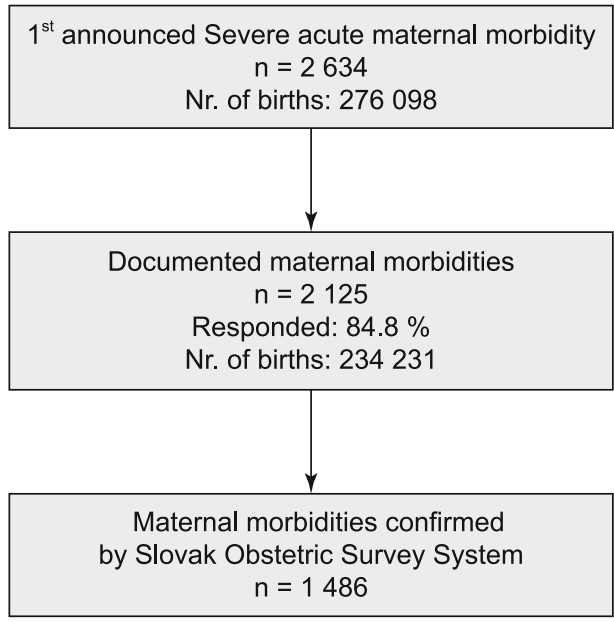

Fig. 1. Slovak Obstetric Survey System process of evaluation of severe acute maternal morbidities (source: SOSS).

The average gestational age in occurrence of SAMM was 35.7 (21-42) weeks. Each maternal morbidity has own specifics, that can be seen also on the population parameters. The youngest were pregnant women suffered from eclampsia and oldest were women suffered from non-fatal amniotic fluid embolism or uterine rupture. The highest parity was among women those undergone peripartum hysterectomy. The lowest gestational age was in hypertensive disorders in pregnancy (e.g. eclampsia and HELLP syndrome). The detailed analyses of epidemiological data are in the Table 3.

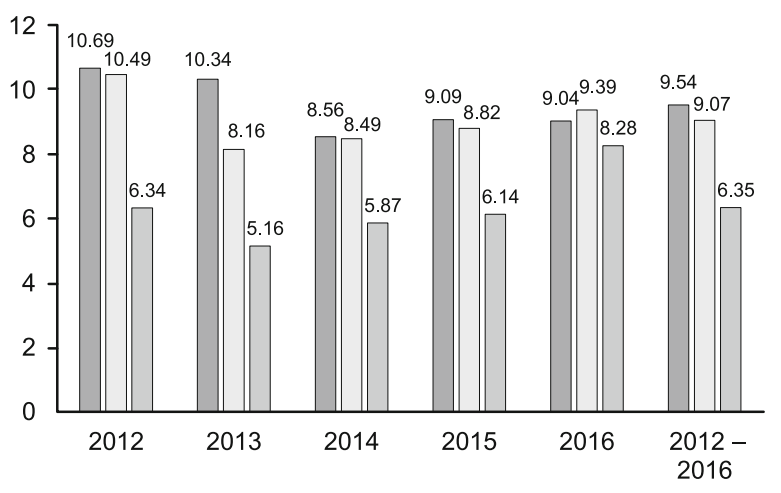

$\square$ Firstly announced SAMM $\square$ Documented SAMM
$\square$ Confirmed SAMM

Fig. 2. The incidence (per 1,000 births) of severe acute maternal morbidity (SAMM) in Slovakia in the years 2012-2016 (source: SOSS).

\section{Discussion}

Maternal mortality and severe acute maternal morbidity are observed indicators of health care quality in the country $(2,7,11)$. Incidence of SAMM in the world vary from 6.0/1,000 live births in Australia till 13.9/1,000 live births in France, and in developing countries even higher, however everything depends from the definition and which causes of SAMM are included to observation $(2,12$, 13). Incidence of SAMM in Netherlands (with similar definition as SOSS) was slightly higher (7.1/1,000 births) than in Slovakia (14).

Tab. 2. The incidence (per 1,000 births) of severe acute maternal morbidity (SAMM) in Slovakia in the years 2012-2016 (source: SOSS).

\begin{tabular}{|c|c|c|c|c|c|c|}
\hline \multirow{2}{*}{ Severe acute maternal morbidity } & \multicolumn{6}{|c|}{ Years } \\
\hline & 2012 & 2013 & 2014 & 2015 & 2016 & $2012-2016$ \\
\hline Severe peripartum haemorrhage & 2.32 & 1.77 & 1.84 & 2.26 & 2.3 & 2.10 \\
\hline Transport to intensive care unit or anaesthesiology & 1.46 & 1.00 & 1.23 & 1.37 & 2.26 & 1.46 \\
\hline Peripartum hysterectomy & 0.72 & 0.83 & 0.80 & 0.76 & 1.09 & 0.84 \\
\hline HELLP syndrome & 0.66 & 0.56 & 0.78 & 0.36 & 0.79 & 0.63 \\
\hline Uterine rupture & 0.27 & 0.29 & 0.54 & 0.79 & 0.98 & 0.57 \\
\hline Abnormally invasive placenta & 0.37 & 0.50 & 0.30 & 0.33 & 0.36 & 0.37 \\
\hline Sepsis & 0.21 & 0.08 & 0.15 & 0.15 & 0.29 & 0.18 \\
\hline Non-fatal amniotic fluid embolism & 0.04 & 0 & 0.02 & 0 & 0.02 & 0.02 \\
\hline Overall SAMM & 6.34 & 5.16 & 5.87 & 6.14 & 8.28 & 6.35 \\
\hline
\end{tabular}

Tab. 3. The selected epidemiological data of severe acute maternal morbidity (SAMM) (source: SOSS).

\begin{tabular}{|c|c|c|c|c|}
\hline Severe acute maternal morbidity & $\mathrm{n}$ & Age (years) & Parity & Gestational week \\
\hline Severe peripartum haemorrhage & 489 & $31.03(16-46)$ & $1.23(0-12)$ & $37.17(24-41)$ \\
\hline Transport to intensive care unit or anaesthesiology & 342 & $29.93(15-41)$ & $1.20(0-13)$ & $35.26(21-42)$ \\
\hline Peripartum hysterectomy & 197 & $32.64(16-43)$ & $2.25(0-15)$ & $36.42(25-42)$ \\
\hline HELLP syndrome & 149 & $30.23(14-41)$ & $0.39(0-4)$ & $34.26(21-40)$ \\
\hline Uterine rupture & 131 & $32.27(20-41)$ & $1.75(0-11)$ & $38.18(29-41)$ \\
\hline Abnormally invasive placenta & 88 & $31.91(19-41)$ & $1.84(0-8)$ & $36.35(25-41)$ \\
\hline Eclampsia & 45 & $24.54(16-41)$ & $0.36(0-4)$ & $33.34(24-41)$ \\
\hline Non-fatal amniotic fluid embolism & 4 & $33.25(28-39)$ & $1.00(0-3)$ & $35.25(21-41$ \\
\hline Overall SAMM & 1486 & $30.28(14-46)$ & $1.16(0-15)$ & $35.74(21-42)$ \\
\hline
\end{tabular}


The most often cause of SAMM in Slovakia was the peripartum haemorrhage which is also the leading cause of maternal mortality in the world $(7,11,15)$. In more than half of the cases severe peripartum haemorrhage was the cause of the transport to intensive care unit or anaesthesiology in Slovakia. In comparison with Slovak incidence 2.1/1,000 births, the incidence of severe peripartum haemorrhage was higher in Netherlands (the same definition) the incidence of peripartum haemorrhage was 4.5/1,000 births, in Scotland 3.7/1,000 births (definition -5 and more transfusion units of red blood cells given, or blood loss $\geq 2,500 \mathrm{ml}$ ) and lower in Norway $1,1 \%$ of births (definition - blood loss $\geq 1,500$ $\mathrm{ml}$ or need for transfusion therapy) $(14,16,17)$.

The incidence of peripartum hysterectomy in Slovakia is in the other ten countries in Europe like France, Portuguese or Switzerland $(10,18)$. According to the studies peripartum hysterectomy and peripartum haemorrhage are more common by caesarean section than in the vaginal birth (19). The overall frequency of caesarean section in Slovakia during years 2012-2016 was around $30 \%(20-24)$.

The incidence of uterine rupture was increasing during the observation years in Slovakia (since 0.27 in the year 2012 to 0.98 in the year 2016); however, this increase is mostly due to better surveillance and documentation (20-24).

The abnormally invasive placenta in the years 2012-2016 varied between $0.3-0.5 / 1,000$ births in Slovakia. Expert analyses disclosed insufficient antenatal diagnosis of abnormally invasive placenta. Overall detection rate varied during the observing period between $38.5-77.3 \%$ (25).

HELLP syndrome in Slovakia varied from 0.36 till 0.79/1,000 births during the observed period. HELLP syndrome in Slovakia was mainly associated with higher age ( $>30$ years), nulliparity, pregnancies after the assisted reproductive technologies and multiple pregnancies (26).

Eclampsia had lower frequency in Slovakia because of generally good antenatal care (out of some margin ethnic group), however the women suffered from eclampsia were among the youngest, with the lowest parity and gestational age within women with SAMM (20-24).

The incidence of sepsis varies from $0.1-0.6 / 1,000$ births in developed countries. In the United Kingdom sepsis was the most often cause of maternal mortality in years 2006-2008 (1.13/100,000 births), with a decrease in years 2009-2011 (0.5/100,000 births). However, in counting of all sepsis genital one together with infection of urinary system, pneumonia or influenza, the mortality has raised to 2.04/100,000 births (27-29). In Slovakia the influenza H1N1 had dominant place in the aetiopathogenesis of maternal mortality due to sepsis in last decade $(10,30)$.

The nonfatal amniotic fluid embolism is very complicated for diagnosis, as the diagnosis is one of per exclusionem. In Slovakia amniotic fluid embolism was the leading cause of maternal mortality in last decade. During observed period 4 cases of nonfatal amniotic fluid embolism were confirmed. These women had highest average age within the SAMM group patients.

The study presents the first 5-years aggregated data from Slovakia of these severe maternal morbidities. However, study had some limitation because of loss date from non-responding hospitals. Probably on-line system would be more flexible to acquire more data.

\section{Conclusion}

The regular audit of SAMM is very important to obtain real incidence of all morbidities. For learning from these cases and up-date clinical day-to-day practice are these data very important too. Data analysis offer improvement of prevention, diagnosis and management these SAMM. It is necessary to go further and involved analyses with controlled group. The appropriate awareness of public is also one of the big challenges of SOSS.

\section{References}

1. Kristufkova A, Korbel M, Borovsky M et al. Analyses of severe acute maternal morbidity in Slovak Republic in year 2012. Gynekol prax 2015; 13 (4): 185-191.

2. Geller SE, Koch AR, Garland CE et al. A global view of severe maternal morbidity: moving beyond maternal mortality. Reprod Health 2018; 15 (Suppl 1): 98.

3. Knight M. The International Network of Obstetric Survey Systems (INOSS): benefits of multi-country studies of severe and uncommon maternal morbidities. Acta Obstet Gynecol Scand 2014; 93 (2): 127-131.

4. INOSS. Randolph Concordat 2010. www.npeu.ox.ac.uk/downloads/files/inoss/misc/Randolph-concordat-v3-July-2010.pdf [visited 19.5.2019]

5. Kristufkova A, Borovsky M, Korbel M, Knight M. Amniotic fluid embolism - investigation of fatal cases in Slovakia in the years 2005-2010 compared with fatal cases in the United Kingdom. Biomed Pap med Fac Univ Palacky Olomouc Czech Repub 2014; 158 (3): 397-403.

6. Kristufkova A, Korbel M, Borovsky M, Knight M. Comparison of outcomes of perinatal care in Slovakia and the UK. Int J Gynaecol Obstet 2013; 123 (2): 131-134.

7. Korbel M, Kristufkova A, Danis $\mathbf{J}$ et al. Maternal morbidity and mortality in Slovak Republic in the years 2007-2015. Ces Gynek 2019; 84 (2): 129-139.

8. Kristufkova A, Korbel M, Danis J et al. Analyses of severe acute maternal morbidity in Slovak Republic in the year 2013. Gynekol prax 2016; 14 (2): 92-98.

9. Kristufkova A, Korbel M, Danis J et al. Analyses of severe acute maternal morbidity in Slovak Republic in the year 2014. Gynekol prax 2017; 15 (1): 25-32.

10. Kristufkova A, Korbel M, Danis J et al. Analysis of severe acute maternal morbidity in the Slovak republik in the year 2015. Gynekol prax 2019; 17 (2): 83-90.

11. Korbel M, Kristufkova A, Dugatova M et al. Analysis of maternal morbidity and mortality in Slovak Republic in the years 2007-2012. Ces Gynek 2017; 82 (1): 6-15.

12. Jayaratnam S, Burton A, Connan KF et al. Maternal 'near miss' at Royal Darwin Hospital: An analysis of severe maternal morbidity at an Australian regional tertiary maternity unit. Aust N Z J Obstet Gynaecol 2016; 56 (4): 381-386. 
690-694

13. Deneux-Tharaux C, Bouvier-Colle M-H, EPIMOMS Study Group. Severe acute maternal morbidity in France: the epimoms population-based study. Am J Obstet Gynecol 2017; 216: S345-S346.

14. Zwart JJ, Richters JM, Ory F et al. Severe maternal morbidity during pregnancy, delivery and puerperium in the Netherlands: a nationwide population-based study of 371,000 pregnancies. BJOG 2008; 115 (7): 842-850.

15. Bouvier-Colle MH, Mohangoo AD, Gissler M et al. What about the mothers? An analysis of maternal mortality and morbidity in perinatal health surveillance systems in Europe. BJOG 2012; 119 (7): 880-889.

16. Brace V, Kernaghan D, Penney G. Learning from adverse clinical outcomes: major obstetric haemorrhage in Scotland, 2003-05. BJOG 2007; 114 (11): 1388-1396.

17. Al-Zirqi I, Vangen S, Forsen L, Stray-Pedersen B. Prevalence and risk factors of severe obstetric haemorrhage. BJOG 2008; 115 (10): 1265 1272 .

18. European Perinatal Health Report. Health and care of pregnant women nad babies in Europe in 2010. May 2013. Available www.europeristat.com [visited 28.6.2019]

19. Knight M, Kurinczuk JJ, Spark P, Brocklehurst P. Emergency postpartum hysterectomy for uncontrolled postpartum bleeding: a systematic review. Obstet Gynecol 2010; 115 (6): 1306-1307.

20. Korbel M, Borovsky M, Niznanska Z et al. Analyses of maternal morbidity in Slovak republic in year 2012. Gynekol prax 2014; 12 (1): 13-19.

21. Korbel M, Borovsky M, Danko J et al. Analyses of maternal morbidity in Slvoak Republic in year 2013. Gynekol prax 2015; 13 (4): 160-166.

22. Korbel M, Borovsky M, Danko J et al. Analyses of maternal morbidity in Slovak Republic in year 2014. Gynekol prax 2016; 14 (2): 66-72.
23. Korbel M, Kristufkova A, Dugatova M et al. Analyses of maternel morbidity in Slovak Republic in the year 2015. Gynekol prax 2017; 15 (1): 18-24.

24. Korbel M, Kristufkova A, Danis J et al. Maternal morbidity in Slovak Republic in the year 2016. Gynekol prax 2018; 16 (1): 19-26.

25. Levayova B, Korbel M, Kristufkova A et al. Analysis of abnormally invasive placenta cases in the Slovak Republic in the years $2012-2015$. Gynekol prax 2019; 17 (2): 96-99.

26. Dugatova M, Kristufkova A, Nemethova B et al. Active surveillance of incidence and risk factors of hemolysis, elevated liver enzymes and low platelets syndrome in Slovakia. Bratisl Med J 2018; 119 (12): 785-789.

27. Cantwell R, Clutton-Brock T, Cooper G et al. Saving Mothers' Lives: Reviewing maternal deaths to make motherhood safer: 2006-2008. The Eighth Report of the Confidential Enquiries into Maternal Deaths in the United Kingdom. BJOG 2011; 118 Suppl 1:1-203.

28. Mohamed-Ahmed O, Nair M, Acosta C et al. Progression from severe sepsis in pregnancy to death: a UK population-based case-control analysis. BJOG 2015; 122 (11): 1506-1515.

29. Knight M, Kenyon S, Brocklehurst $P$ et al. Saving Lives, Improving Mothers' Care - Lessons Learned to Inform Future Maternity Care from the UK and Ireland Confidential Enquiries into Maternal Deaths and Morbidity 2009-2012. Oxford National Perinatal Epidemiology Unit, University of Oxford, 2014.

30. Korbel M, Borovsky M, Danko J et al. Maternal mortality in Slovak Republic in the years 2010 - 2012. Gynekol prax 2015; 13 (4): 192-195.

Received June 28, 2019. Accepted July 8, 2019. 